Marcin Popiel

Uniwersytet Jagielloński, Kraków, Polska • Jagiellonian University, Krakow, Poland

\title{
Znaczenie turystyki zrównoważonej w rozwoju społeczno-gospodarczym na przykładzie Chorwacii
}

\section{The importance of sustainable tourism in the socio-economic development on the example of Croatia}

\begin{abstract}
Streszczenie: Turystyka jest jednym z największych i jednocześnie najszybciej rozwijających się działów wielu gospodarek na świecie. Każdego roku miliony osób na naszej planecie podróżują. Kiedy przyjeżdżają do danego regionu, mają duży wpływ na destynację turystyczną, lokalną społeczność, środowisko naturalne i zagospodarowanie przestrzenne. Równocześnie na wielu terenach turystyka stanowi główne źródło rozwoju gospodarczego. Ale interesy turystów, lokalnej gospodarki oraz środowiska są często sprzeczne. Rozwój turystyki może spowodować dużo pozytywnych zmian, jak choćby wzrost jakości życia mieszkańców czy napływ kapitału, może też jednak sprowadzić zmiany negatywne. W szczególności są one widoczne w zanieczyszczeniu środowiska, jego nadmiernej eksploatacji, w braku poszanowania dla kultury i historii regionu. Przykładem jest nieprzemyślane zagospodarowanie przestrzenne, w tym budowa „drugich domów” przy zabytkach albo na unikatowych terenach zielonych. Dotychczas rozwój turystyki opierał się na spełnianiu aspiracji przedsiębiorców czy turystów, ich wygodzie oraz interesie, bez przejmowania odpowiedzialności za zachowanie zasobów naturalnych czy dbanie o lokalną społeczność. Obecnie kluczowe znaczenie dla skutecznego zarządzania i pozycjonowania poszczególnych gałęzi gospodarki, zwłaszcza turystyki, ma zrównoważony rozwój. Turystyka również może być zrównoważona, jeżeli jej rozwój zaspokaja potrzeby zarówno turystów, jak i lokalnych mieszkańców, przy jednoczesnym zachowaniu i ochronie zasobów materialnych i niematerialnych. Cel niniejszego artykułu jest poznawczy - prezentacja zasad zrównoważonego rozwoju na przykładzie sektora turystycznego w Chorwacji. Przedmiotem badania jest analiza pozytywnego i negatywnego wpływu turystyki na destynację turystyczną, lokalną społeczność, środowisko i gospodarkę. Autor pragnie wykazać, iż poprzez wprowadzenie modelu zrównoważonego rozwoju turystyki można uzyskać wzrost społeczno-gospodarczy oraz ogólną stabilność i równowagę regionu.
\end{abstract}

\begin{abstract}
Tourism is one of the largest and simultaneously the most rapidly expanding industries in the world. Every year, millions of people across the planet are involved in the act of travelling. When vast numbers of tourists travel to a particular location, a tourist destination, they have a considerable impact on the local community and environment, spatial planning and more. Moreover, in many regions, tourism is a major source of economic development. However, often the interests of the tourism sector and the local economy are incompatible with those of the environment. The development of tourism in many cases can cause many positive changes, such as raising the standard of living, the inflow of cap-
\end{abstract}


ital, although - as often happens - along with numerous positive changes, the development of tourism can cause a series of negative changes. These are visible, in particular, in air pollution, overexploitation of the environment, lack of respect for a region's culture and history, such as non-planned activities and building "second homes" near monuments or on a unique green area. So far, the development of tourism was based on meeting the aspirations of entrepreneurs and tourists, their convenience and interest, without caring about the interests of conserving natural resources or caring for the local community. At present, what is crucial for the successful management and also for the market positioning of each particular branch of the economy, especially tourism, is sustainable development. Tourism can also be sustainable if the development meets the needs of both tourists and local residents, whilst preserving and protecting both tangible and intangible assets. The aim of this article is the presentation of the principles of sustainable development based on the example of the tourism sector in Croatia. The objective of this study is to analyse the positive and negative impact of tourism on tourist destinations, the local community, the environment and the economy. The author wishes to demonstrate that, by introducing a model of sustainable tourism development, it is possible to achieve an increase in socio-economic growth, as well as overall sustainability and balance in the region.

Słowa kluczowe: Chorwacja; turystyka; wpływ ekonomiczny; wpływ społeczny; wpływ środowiskowy; zrównoważony rozwój

Keywords: Croatia; economic impact; environmental impact; social impact; sustainable development; tourism

Otrzymano: 31 grudnia 2014

Received: 31 December 2014

Zaakceptowano: 19 czerwca 2015

Accepted: 19 June 2015

\section{Sugerowana cytacja / Suggested citation:}

Popiel, M. (2015). Znaczenie turystyki zrównoważonej w rozwoju społeczno-gospodarczym na przykładzie Chorwacji. Prace Komisji Geografii Przemystu Polskiego Towarzystwa Geograficznego, 29(3), 67-82.

\section{WSTĘP}

Rozwój turystyki niesie ze sobą zarówno pozytywne, jak i negatywne zmiany, które mogą odnosić się do społeczności lokalnej, jej zwyczajów, kultury, sposobu wypoczynku czy spędzania wolnego czasu. „Turystyka może być narzędziem wspomagającym lub sprzyjającym regeneracji i rozwojowi gospodarczemu, jak również podnosić jakość życia odwiedzających oraz społeczności lokalnej” (Działania..., 2014: 4). A zatem „pozytywny wpływ może być rozpatrywany w aspekcie rozwoju standardu życia mieszkańców - w większości osób zatrudnionych - i zaangażowania społeczeństwa w działalność turystyczną" (KrstinićNižić, Drpić, 2013: 159). Korzystają na tym również turyści, którzy - dzięki rozwojowi sektora turystycznego - mogą czerpać przyjemność z dobrej jakości usług i produktów, a także z nowych atrakcji wyłanianych na podstawie waloryzacji i eksploatacji istniejących zasobów turystycznych. Jednakże - jak większość zjawisk - i rozwój turystyki, poza wzniosłymi celami i pozytywnymi skutkami, niesie ze sobą wiele negatywnych konsekwencji. Turystyka i jej rozwój mają szczególny związek z innymi dziedzinami gospodarki, ze środowiskiem naturalnym czy społeczeństwem. Ta relacja spowodowana jest „wyjątkową zależnością turystyki 
od dobrej jakości środowiska, różnorodności kulturowej oraz społecznej interakcji, poczucia bezpieczeństwa i dobrobytu" (Działania..., 2014: 4). Źle zaplanowana lub nadmiernie rozwinięta turystyka może więc prowadzić przede wszystkim do zanieczyszczenia środowiska (problem ścieków, zanieczyszczenia wody morskiej, wody pitnej, zanieczyszczenia powietrza), zaburzenia naturalnej równowagi środowiska, zmiany stylu życia mieszkańców, czy upowszechnienia opinii - wśród społeczności lokalnej - że praca sezonowa jest wystarczająca do całorocznego utrzymania, co powoduje znaczne dysproporcje regionalne. Następuje migracja za pracą do regionów turystycznych. Takie podejście może mieć również negatywny wpływ na jakość oferowanych usług i produktów, gdzie w destynacjach wakacyjnych, wypoczynkowych - ograniczonych sezonowością - usługodawcy kierują się chęcią szybkiego zarobku, bez dbania o jakość oferty turystycznej. Idące za tym negatywne skutki mogą być widoczne w nieprzyjaznym wizerunku całej okolicy w odczuciu turystów, jak również w ich słabnącym zaufaniu do usługodawców, co powoduje długoterminową utratę klientów (Krstinić-Nižić, Drpić, 2013).

Rozwój turystyki ma ambiwalentny charakter. „Z jednej strony może być cennym źródłem dochodów i zatrudnienia, potencjalnie działając jako katalizator dla szerszego rozwoju społeczno-gospodarczego, z drugiej zaś strony - generuje koszty środowiskowe związane z różnego rodzaju degradacją, nieprzemyślaną urbanizacją czy niszczeniem zasobów naturalnych" (Petrić, 2012: 139). Koszty te zwykle wiążą się też z wieloma konsekwencjami gospodarczymi, społecznymi i kulturowymi. Jednak negatywnym skutkom można zapobiegać poprzez systematyczne i skoordynowane wdrażanie środków i działań w branży turystycznej w celu zapewnienia jej zrównoważonego rozwoju.

Głównym celem artykułu jest próba ukazania zrównoważonego rozwoju turystyki oraz jej aspektów i znaczenia dla rozwoju społeczno-gospodarczego regionu. Poprzez prezentację skutków rozwoju masowej turystyki autor pragnie pokazać możliwości, jakie daje wprowadzenie modelu zrównoważonego rozwoju turystyki. Zakres przestrzenny pracy obejmuje teren Chorwacji, jako przykładowej destynacji turystycznej, gdzie turystyka ma bardzo duże znaczenie w życiu społeczno-gospodarczym.

Głównym źródłem informacji była dokumentacja statystyczna Centralnego Biura Statystycznego Chorwacji. Cennym źródłem była również analiza literatury, raportów oraz innych opracowań, których szczegółowy wykaz został zamieszczony w spisie literatury. Dodatkowym źródłem informacji była wiedza autora, który przez wiele lat pracował w Chorwacji jako rezydent i pilot wycieczek, dzięki czemu osobiście zaznajomił się z sektorem turystycznym tego kraju i przeprowadził rozmowy z jego mieszkańcami, co ułatwiło opracowanie niniejszego artykułu.

\section{OBecny STAN TURystyki w ChORWACJI}

Turystyka stanowi najważniejszy dział gospodarki dla Republiki Chorwacji, a także znaczne źródło dochodów, dzięki któremu następuje finansowanie rozwoju społeczno-gospodarczego. Ponadto państwo to „od wielu lat należy do obszarów o dobrze rozwiniętej funkcji turystycznej i dodatnim bilansie w zagranicznych obrotach turystycznych. Turystyka 
w tym kraju jest źródłem takich korzyści, jak wzrost produktu krajowego brutto, wpływów dewizowych, przychodów publicznych, zatrudnienia i dochodów ludności oraz rozwoju regionalnego. Ekonomiczna funkcja turystyki jest widoczna w wielu sferach gospodarowania, a w szczególności powoduje ona zróżnicowanie w przestrzennej strukturze podziału dochodu narodowego wytwarzanego przez turystykę" (Rettinger, 2010: 450).

Według Centralnego Biura Statystycznego w Chorwacji w 2013 roku zarejestrowano 12,442 mln pobytów turystycznych, z czego 1,486 mln stanowiły przyjazdy krajowe, natomiast $10,955 \mathrm{mln}$ to przyjazdy turystów z zagranicy. W obserwowanym okresie odnotowano łącznie 64,827 mln noclegów, z których 5,139 mln to noclegi turystów krajowych, zaś 59,688 mln noclegów zostało wykorzystanych przez turystów zagranicznych. Większość przyjazdów w 2013 roku $(7,748 \mathrm{mln})$ to przyjazdy indywidualne, natomiast zorganizowanych zostało 4,693 mln pobytów (Tourism in Figures 2013, 2014).

Analizując strukturę gości przyjeżdżających do Chorwacji w 2013 roku, zauważyć można, iż najwięcej pochodziło ich z Niemiec (1,933 mln turystów, stanowiących 17,6\% wszystkich odwiedzających), następnie ze Słowenii (1,067 mln osób, które stanowiły 9,7\% wszystkich turystów). Trzecią narodowością licznie odwiedzającą Republikę Chorwacji w 2013 roku byli Włosi. Przyjechało ich wówczas 1,017 mln. Według Centralnego Urzędu Statystycznego w obserwowanym okresie zarejestrowano 0,636 mln przyjazdów turystów z Polski, którzy stanowili 5,8\% w całej strukturze pobytów (Tourism in Figures 2013, 2014).

W 2013 roku najwięcej turystów wybrało hotel jako miejsce zakwaterowania (4,842 mln), skorzystali oni łącznie z 16,751 mln noclegów. Drugą najczęściej wybieraną kategorią bazy noclegowej były kwatery prywatne. Wybrało je 3,167 mln osób, które skorzystały z 22,132 mln noclegów. Można zatem dostrzec, iż średnia długość noclegów w hotelach wyniosła trzy i pół doby, natomiast w kwaterach prywatnych - siedem dób (Tourism in Figures 2013, 2014).

Po analizie przestrzennej zależności można zauważyć, że największa liczba turystów gościła w żupaniach: istryjskiej (Istria) - 2,981 mln pobytów, primorsko-gorskiej (Primorje - Gorski Kotar) - 2,38 mln pobytów, splicko-dalmatyńskiej (Split - Dalmacja) - 2,038 mln turystów oraz dubrownicko-neretwiańskiej (Dubrownik - Neretwa) - 1,241 mln pobytów (Tourism in Figures 2013, 2014) (ryc. 1).

Na podstawie powyższych danych widać, że przybrzeżna i wyspiarska część Chorwacji są najchętniej odwiedzane przez turystów, można też zauważyć idące za tym konsekwencje. W kraju nastąpiła widoczna dysproporcja regionalna. Obszary wiejskie - wewnątrz kraju, w jego kontynentalnej części - straciły swój gospodarczy i społeczny wpływ, który był uwarunkowany ich historią (Krstinić-Nižić, Drpić, 2013). Kładzie się główny nacisk na rozwój linii brzegowej ze względu na możliwości turystyczne tego terenu. ,Region ten charakteryzuje się wysokimi walorami przyrodniczymi oraz kulturowymi, które zdecydowały o długoletnich tradycjach rozwoju turystyki w tym regionie. Obszar ten obfituje w śródziemnomorskie krajobrazy, piaszczyste plaże, malownicze wioski i starożytne miasta, których rozkwit przypadał na okres imperium rzymskiego" (Rettinger, 2010: 451). 
Ryc. 1. Podział administracyjny Chorwacji na żupanie

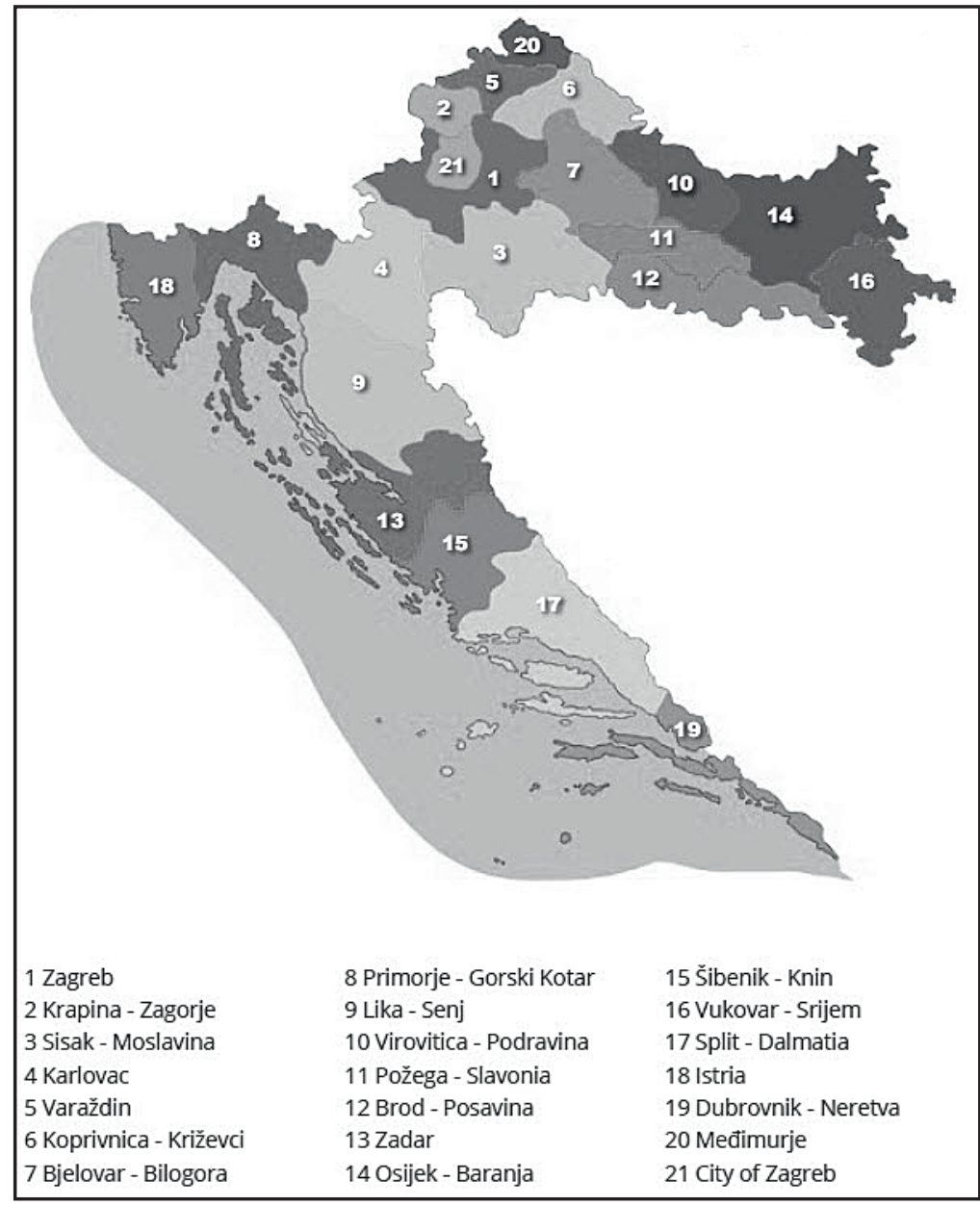

Źródło: Tourism in Figures 2013, 2014

Po przeprowadzeniu analizy SWOT dla rozwoju turystyki w Chorwacji można zidentyfikować następujące mocne i słabe strony oraz szanse i zagrożenia.

\section{Mocne strony:}

- zasoby naturalne: bogactwo i różnorodność krajobrazu (rozwinięta linia brzegowa, klimat śródziemnomorski, duża kontrastowość wybrzeża),

- położenie geograficzne: zewnętrzna dostępność przestrzenna,

- ludzie: wykwalifikowane zasoby pracy w turystyce,

- gospodarka: możliwość rozwoju rolnictwa, handlu oraz usług paraturystycznych,

- komunikacja: rozbudowana sieć infrastruktury komunikacyjnej (drogi, porty międzynarodowe, lotniska międzynarodowe, dworce kolejowe, mosty, rury wodociągowe, sieci telekomunikacyjne itd.), 
- zasoby: potencjał rozwojowy różnych form turystyki (nurkowanie, turystyka rekreacyjna, polowania, wędkarstwo, agroturystyka, turystyka tematyczna, turystyka biznesowa itp.),

- bezpieczeństwo: poczucie bezpieczeństwa zarówno w aspekcie zakwaterowania, jak i regionu,

- gastronomia: kuchnia regionalna,

- kultura: materialne i niematerialne dziedzictwo kulturowe i różnorodność kulturowa.

\section{Slabe strony:}

- ochrona środowiska: nieefektywna (zanieczyszczenia źródeł wody, gospodarka odpadami),

- zasoby: słabe wykorzystanie regionalnych zasobów (morze, wyspy itp.),

- problemy z zaopatrzeniem w wodę,

- widoczne skutki wojny: zniszczone obiekty dalej niewyremontowane,

- sezonowość turystyki,

- często niska jakość usług w sektorze prywatnym (kwatery prywatne),

- brak sprawnego zarządzania i słaba strategia rozwoju regionalnego.

\section{Szanse:}

- bardzo dobre położenie komunikacyjne Chorwacji (dostępność fizyczna, czasowa, ekonomiczna),

- bliskość rynków turystycznych: Bośni i Hercegowiny, Czarnogóry, Słowenii, Albanii,

- zwiększone zainteresowanie turystów Chorwacją jako destynacją turystyczną,

- inwestowanie w różne formy turystyki (turystyka kongresowa, zdrowotna, golfowa, biznesowa itd.),

- popularność produktów regionalnych,

- stabilizacja polityczna i gospodarcza na Bałkanach,

- członkowstwo w Unii Europeskiej, poprawa sieci komunikacyjnej (lotnisko w Dubrowniku i Splicie, połączenia kolejowe, autostrady),

- klimat śródziemnomorski,

- bogate zasoby naturalne,

- różnorodność kulturowa.

\section{Zagrożenia:}

- zwiększona konkurencja ze strony destynacji turystycznych w Europie,

- brak współpracy na szczeblach politycznych, samorządowych i lokalnych,

- klęski żywiołowe: trzęsienia ziemi, pożary w okresie letnim, silne wiatry, opady deszczu latem i niewystarczający poziom zapobiegania katastrofom,

- zanieczyszczenie środowiska,

- wyższe ceny nieruchomości,

- wyższe ceny artykułów spożywczych,

- migracje: depopulacja ludności autochtonicznej i wyjazdy młodych i wykształconych ludzi,

- wpływ społeczny: przestępczość, korupcja, alkohol, narkotyki, prostytucja (Popiel, Ziółkowska-Weiss, 2013; Ruoss, Alfarè, 2013). 


\section{SkUtKi ROzWOJU MASOWEJ TURYSTYKI w CHORWACJI}

Turystyka jest ściśle połączona z innymi dziedzinami gospodarki, wpływa też na środowisko naturalne i społeczeństwo. Jej rozwój może dostarczać wiele pozytywnych zmian, jednakże źle zaplanowana lub też nadmiernie rozwinięta turystyka może przyczynić się do niszczenia czy wprowadzania negatywnych skutków dla wymienionych wyżej elementów, które mają kluczowe znaczenie dla kraju i jego rozwoju. Wśród pozytywnych skutków rozwoju turystyki M. Krstinić-Nižić i D. Drpić (2013) wyróżniają m.in.:

- wzrost dobrobytu i poziomu życia,

- wzrost poziomu zatrudnienia,

- silniejsze więzi intelektualne różnych grup ludzi.

Poza pozytywnymi skutkami należy skupić się również na negatywnych aspektach rozwoju turystyki. Przede wszystkim ma to swoje odzwierciedlenie w środowisku naturalnym. Według Neto (2003) wpływ rozwoju turystki na naturę przejawia się na dwa sposoby:

- nadużywanie zasobów naturalnych,

- uszkodzenie ekosystemów.

Jest to paradoksalne, gdyż zanieczyszczenie środowiska podważa działalność turystyczną. Jej aktywa fizyczne stają się przez to mniej atrakcyjne, a nawet mogą stanowić zagrożenie dla zdrowia i bezpieczeństwa, co przyczynia się do pogorszenia stopnia satysfakcji użytkowników.

Na różnorodność biologiczną wpływają także - w negatywny sposób - często niezaplanowane lub niewystarczająco kontrolowane przez nadzór budowy turystycznych (komercyjnych) obiektów oraz drugich domów w miejscach bogatych w różnorodność biologiczną i kulturową. Turystyka masowa więc na wiele sposobów powoduje utratę tej różnorodności (Krstinić-Nižić, Drpić, 2013). Jednakże nie tylko turystyka masowa działa w sposób negatywny na środowisko w Chorwacji, również selektywna oferta turystyczna, w rozumieniu np. turystyki żeglarskiej, rybackiej czy nurkowania. Jeśli aktywności te są przeprowadzane w sposób niezorganizowany lub nienadzorowany, mogą wpływać niekorzystnie na faunę i florę.

Kolejnym negatywnym skutkiem rozwoju turystyki jest nadmierne zużycie wody, energii czy jedzenia przez turystów. Powoduje to powstawanie wielu odpadów i ścieków, które mogą zanieczyszczać środowisko, a koszty ich utylizacji rosną. Turyści również bezpośrednio szkodzą środowisku poprzez nieodpowiednie zachowanie i wyrzucanie odpadów, co w wielu przypadkach prowadzi do powstawania pożarów, tak częstych w Chorwacji (Tourism in Figures 2013, 2014).

Pomimo więc pozytywnego wydźwięku rozwoju turystyki i widocznego wzrostu jej udziału w PKB oraz spadku poziomu bezrobocia, społeczność lokalna od fazy radości - wynikającej z możliwości, jakie oferuje turystyka dla danego regionu - przeszła w fazę irytacji. Doxey (1975) zauważył, iż społeczność lokalna danej destynacji - która przeżywa rozwój turystyki - doświadcza czterech faz. Są to:

- euforia (w początkowym stadium rozwoju turystyki),

- apatia (w trakcie rozwoju, kiedy turystyka stała się już częścią życia lokalnej społeczności), 
- rozdrażnienie (zaczyna się w momencie, gdy turystyka zaczyna komplikować codzienne życie społeczności lokalnej - problem przeludnienia, zniszczenie krajobrazu, wzrost cen, thum w okresie letnim),

- antagonizm (pojawia się zachowanie nastawione przeciwko turystyce) (ryc. 2).

Ryc. 2. Cykl życia destynacji turystycznej oraz zadowolenie społeczności lokalnej z rozwoju turystyki

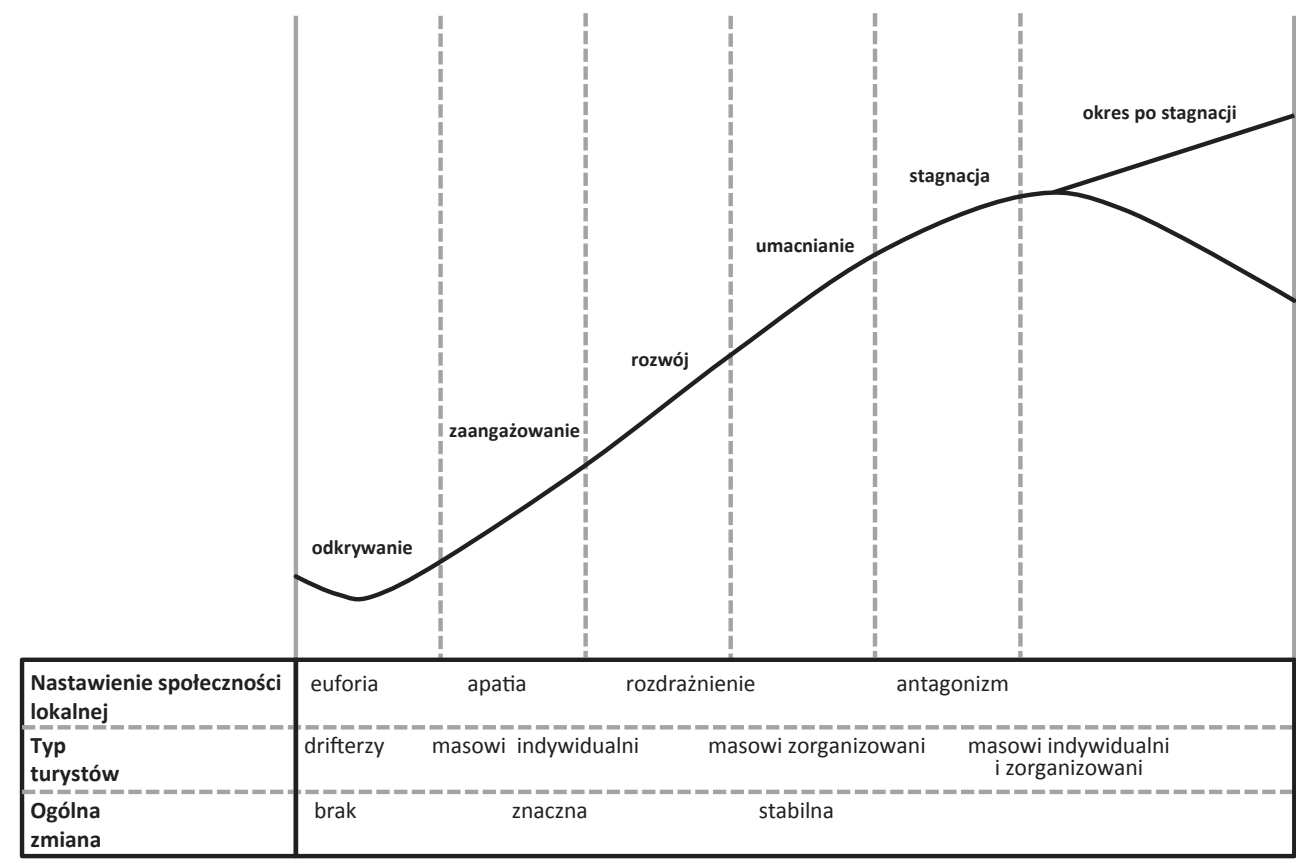

Źródło: opracowanie własne na podstawie: Andriotis (2006: 1080)

Rozwój destynacji turystycznej jest procesem złożonym, który ściśle wiąże się z klientami, społecznością przyjmującą oraz środowiskiem w aspekcie ekonomicznym, fizycznym czy społeczno-kulturowym (Mathieson, Wall, 1982). R.W. Butler (1980) wyróżnia kilka etapów ewolucji destynacji turystycznej, które następują po sobie w przewidywalnej sekwencji. Są to: eksploracja, zaangażowanie, konsolidacja, stagnacja oraz okres po stagnacji. Prowadzą one do odkrywania regionu, jego możliwości i predyspozycji do pełnego rozwoju turystyki. Wiąże się to również z rodzajem turystów, w początkowej fazie rozwoju destynacji podróżują drifterzy, a w miarę ewolucji napływa coraz więcej masowych turystów (Cohen, 1972).

K. Andriotis (2006) łączy cykl życia destynacji turystycznej z zachowaniem społeczności lokalnej. Autor wyróżnia fazę euforii, która pojawia się w początkowym etapie rozwoju turystyki (badań) i fazę apatii w momencie wprowadzenia oferty na rynek i pojawienia się tzw. drifterów, którzy nastawieni są na maksymalną integrację z kulturą danego miejsca. $\mathrm{W}$ tej fazie nie następują żadne znaczące zmiany w środowisku. W ramach rozwoju pojawia się etap apatii, natomiast etap wzrostu i dojrzałości oferty turystycznej prowadzi do dyskomfortu (czyli pojawia się pierwszy negatywny wpływ turystyki na społeczność). Etap 
ten charakteryzuje się wizytą masowych turystów (zarówno indywidualnych, jak i zorganizowanych), mających znaczący wpływ na społeczność oraz środowisko. W okresie stagnacji i po stagnacji u społeczności lokalnej często pojawia się uczucie antagonizmu i niechęci do turystyki (Krstinić-Nižić, Drpić, 2013).

Również w Chorwacji mieszkańcy zaczęli zdawać sobie sprawę z negatywnych skutków rozwoju turystyki. Jednym z czołowych problemów była nadmierna i często nieplanowana budowa drugich domów w obszarach atrakcyjnych turystycznie, przy braku poszanowania tradycyjnej, lokalnej architektury i historii. Kolejnym negatywnym problemem, który przyczynił się do antagonizmu ze strony mieszkańców, było wykorzystywanie terenów szczególnie atrakcyjnych - głównie wzdłuż wybrzeża - i ich adaptacja na potrzeby turystyki (betonowanie plaż, zamulanie morza) oraz budowa infrastruktury (parkingi, baza gastronomiczna na plażach i, co za tym idzie, zwiększona ilość odpadów). To wszystko powoduje nieodwracalne zniszczenia (Krstinić-Nižic, Ivanović, Drpić, 2009).

Lokalnie turystyka w Chorwacji postrzegana jest jako możliwość rozwoju regionalnego poprzez tworzenie miejsc pracy oraz korzyści dla lokalnego biznesu. Niemniej jednak turystyka przynosi też koszty. Przede wszystkim rozwój turystyki pociąga za sobą obciążenie finansowe dla władz lokalnych, które winny inwestować w obsługę ruchu turystycznego, zwłaszcza po wejściu Chorwacji do Unii Europejskiej. Konsekwencje rozwoju turystyki widoczne są również w nieodwracalnych szkodach zarówno dla środowiska naturalnego, jak i dla dziedzictwa kulturowego. Ponadto turystyka jako źródło dochodu jest dość niestabilna, gdyż uzależniona jest głównie od warunków atmosferycznych i charakteryzuje się sezonowością.

\section{ASPEKTY ZRÓWNOWAŻONEGO ROZWOJU}

Nie ma jednej, powszechnie akceptowalnej definicji zrównoważonego rozwoju. „Idea zrównoważonego rozwoju została szeroko uznana za podstawę planowania i zarządzania sposobem życia obecnie i w przyszłości” (Działania..., 2014: 4). Koncepcja ta ewoluuje, jednakże zawsze obejmuje trzy główne aspekty zrównoważonego rozwoju: gospodarczy, społeczny i środowiskowy (ryc. 3).

Trwałość środowiska i zrównoważony rozwój w aspekcie środowiska naturalnego koncentruje się na ogólnej kondycji systemów ekologicznych. Zrównoważony rozwój społeczny zmierza do zmniejszenia wrażliwości i utrzymania poprawnej kondycji systemów społecznych i kulturowych poprzez wzmocnienie kapitału społecznego oraz równouprawnienie (Petrić, 2012). Zachowanie różnorodności kulturowej, kapitału kultury, wzmocnienie spójności społecznej, partnerstwo oraz wyrobienie sieci powiązań i współpracy są integralnymi elementami tego podejścia (Munasinghe, 2003). „Zrównoważony rozwój gospodarczy jest nastawiony głównie na poprawę dobrobytu ludzi, przede wszystkim poprzez wzrost konsumpcji dóbr i usług. Efektywność ekonomiczna odgrywa kluczową rolę w zapewnieniu zarówno wydajnej alokacji zasobów w produkcji, jak i skutecznych wyborów konsumpcyjnych, które maksymalizują użyteczność" (Petrić, 2012: 121). 
Ryc. 3. Trójkąt zrównoważonego rozwoju

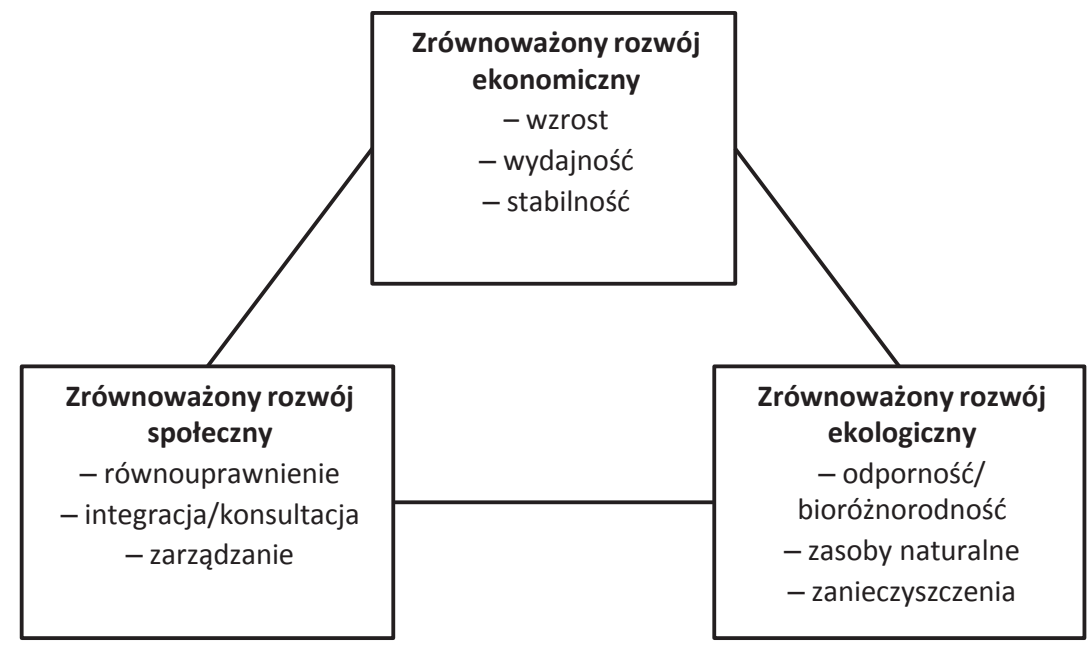

Źródło: opracowanie własne na podstawie Petrić (2012)

\section{TURYSTYKA ZRÓWNOWAŻONA}

„Koncepcja turystyki zrównoważonej wywodzi się ze sformułowanej przez Hetzera w 1965 roku turystyki odpowiedzialnej (ang. responsible tourism), której filarami były minimalizacja ingerencji w środowisko przyrodnicze, poszanowanie odmienności kulturowej, maksymalizacja udziału lokalnej ludności w świadczeniu usług turystycznych, wzrost zadowolenia i satysfakcji turystów” (Kowalczyk, 2011: 38). „Połączenie turystyki z koncepcją rozwoju zrównoważonego, popularyzowaną w ostatnim dwudziestoleciu XX wieku oraz w XXI wieku, dało początek upowszechnianiu pojęcia »turystyka zrównoważona« (ang. sustainable tourism)" (Kowalczyk, 2011: 39). Jednakże - podobnie, jak przy zrównoważonym rozwoju - termin turystyki zrównoważonej nadal nie został jednoznacznie sprecyzowany. Butler (1999) uważa, iż problem nie tkwi w braku definicji, lecz wręcz przeciwnie, w ich nadmiarze, co powoduje szerokie możliwości interpretacji.

J. Swarbrooke (1999) utożsamia turystykę z ideą zrównoważonego rozwoju, zatem jego zdaniem zjawisko zrównoważonej turystyki powinno dotyczyć zwłaszcza znaczenia i wzajemnego oddziaływania na siebie trzech elementów, którymi są: środowisko, społeczeństwo i gospodarka. Według definicji Swarbrooke’a turystyka zrównoważona to taka, która jest silna pod względem gospodarczym, ale nie powoduje niszczenia zasobów, przede wszystkim środowiska fizycznego oraz społeczności lokalnych, od których jest w bezpośredni sposób zależna i od których również zależy jej przyszły rozwój na danym obszarze (Kowalczyk, 2011). W 1993 roku Światowa Organizacja Turystyki (World Tourism Organization) podjęła się zdefiniowania turystyki zrównoważonej, uznawszy, iż jest to zjawisko, które potrafi zaspokoić potrzeby współczesnych turystów oraz regionów recepcyjnych, przy czym 
jednocześnie chroni i wspiera szanse dla przyszłych pokoleń. „Natomiast zgodnie z definicją Komisji Europejskiej turystyka zrównoważona to turystyka, która jest rentowna pod względem gospodarczym i społecznym, nie szkodząc przy tym środowisku i lokalnej kulturze. Oznacza sukces gospodarczy i finansowy, troskę o środowisko, jego ochronę i rozwój oraz odpowiedzialne postępowanie względem społeczeństwa i wartości kulturowych - te trzy elementy są współzależne" (Kowalczyk, 2011: 40).

\section{ZRÓWNOWAŻONA TURYSTYKA A WZROST SPOŁECZNO-GOSPODARCZY CHORWACJI}

Turystyka bardzo silnie rozwinęła się w Chorwacji, jednakże ,zasady zrównoważonego rozwoju - choć instytucjonalnie rozpoznane - nie są realizowane w modelu rozwoju turystyki chorwackiej w żadnym z obszarów czy aspektów zrównoważonego rozwoju. Zatem nie tylko wypracowane wyniki i statystyki dotyczące sektora turystycznego nie oddają rzeczywistych zdolności i chłonności środowiska, ale także obecne zasoby zostały poważnie zagrożone przez rozwój turystyki” (Petrić, 2012: 123). „W ostatnich latach Republika Chorwacka zbyt mało uwagi poświęcała ochronie środowiska i osobliwości krajobrazu poszczególnych miejscowości, zwłaszcza na obszarach przybrzeżnych" (Krstinić-Nižic, Drpić, 2013: 170).

Wszystkie problemy, które wymienione zostały we wcześniejszej części artykułu, można z powodzeniem wyeliminować, jednakże trzeba do tego zgody zainteresowanych stron (przedsiębiorstwa prywatne, publiczne, lokalna społeczność, lokalna administracja itd.). P.E. Murphy (1985: 153) uważa, że „rozwój turystyki opiera się na dobrej woli i współpracy lokalnych ludzi oraz odgórnego zarządzania krajowego, ponieważ są one częścią produktu turystycznego”. „Stąd turystyka, jako lokalna wspólnota pracy, posiadająca silny wpływ na życie społeczeństwa, wymaga proaktywnego podejścia opartego na szerokim udziale zainteresowanych stron, które mogłyby przyczynić się do zwiększenia skuteczności polityki i planów. Zwiększyłoby to możliwości pełnego wykorzystania potencjału społecznego i gospodarczego przemysłu turystycznego" (Petrić, 2012: 123). Najważniejszym celem powinno być odpowiednie zarządzanie, aby utrzymać turystykę w fazie euforii i apatii lokalnej społeczności, gdzie ogólne zmiany wywołane rozwojem turystyki są nieznaczne.

Aby spełnić trzy fundamentalne aspekty zrównoważonego rozwoju, trzeba rozpatrzyć wiele kwestii (ryc. 4).

W świetle przedstawionej na następnej stronie ryciny wzrost społeczno-gospodarczy w Chorwacji, przez zrównoważony rozwój turystyki, można osiągnąć poprzez:

- utworzenie klastrów do wspólnego zarządzania oraz do rozwoju odpowiedzialnej turystyki,

- udział całego społeczeństwa w życiu turystycznym danego regionu,

- wzmocnienie empatii lokalnej społeczności i turystów,

- wzrost świadomości ochrony środowiska,

- umożliwienie edukacji mieszkańców za pośrednictwem instytucji edukacyjnych,

- wzrost rozpoznawalności regionu jako destynacji odpowiedzialnej i zrównoważonej,

- wytworzenie celu lokalnej społeczności i wzmacnianie jej motywacji, 


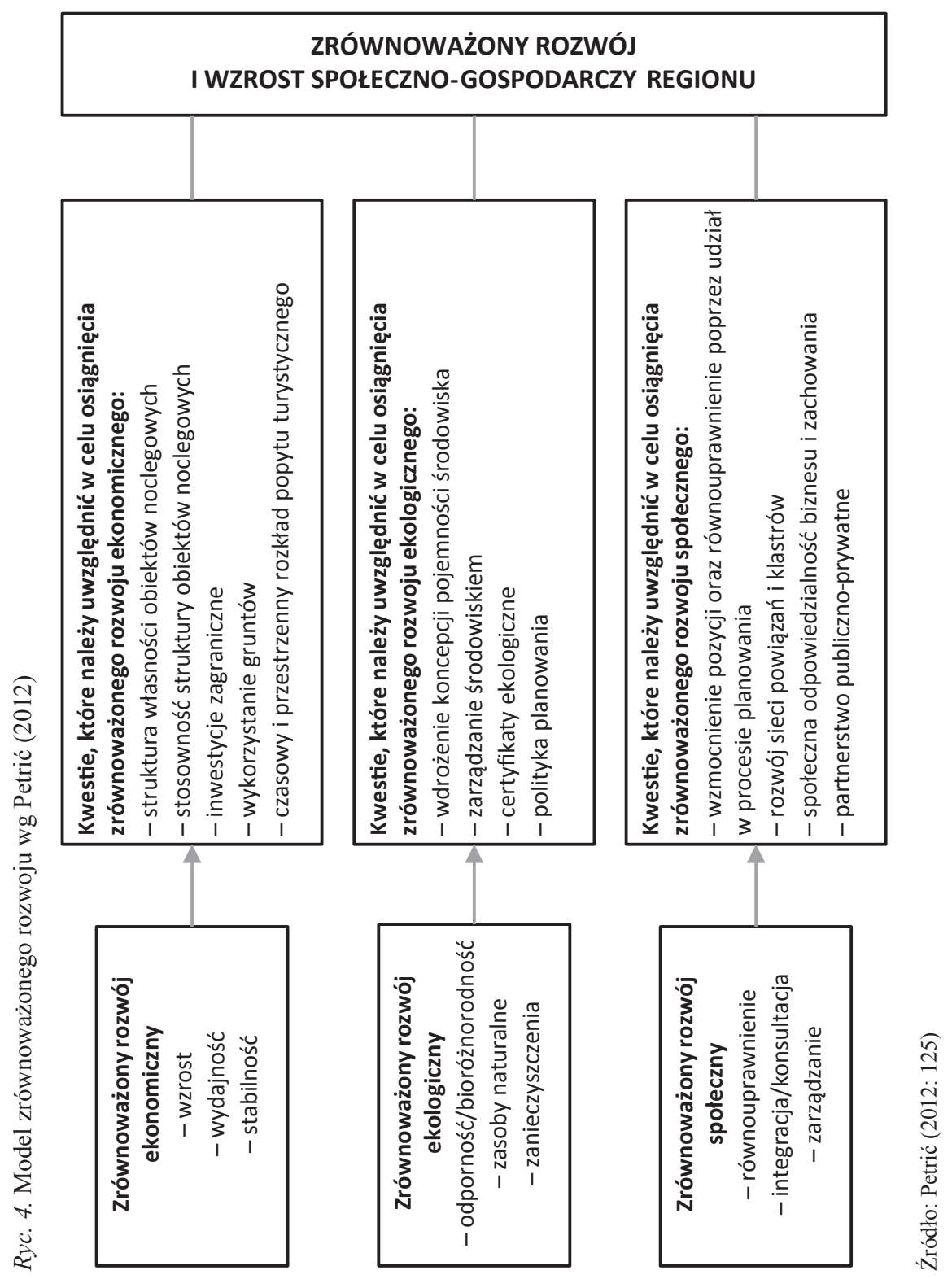




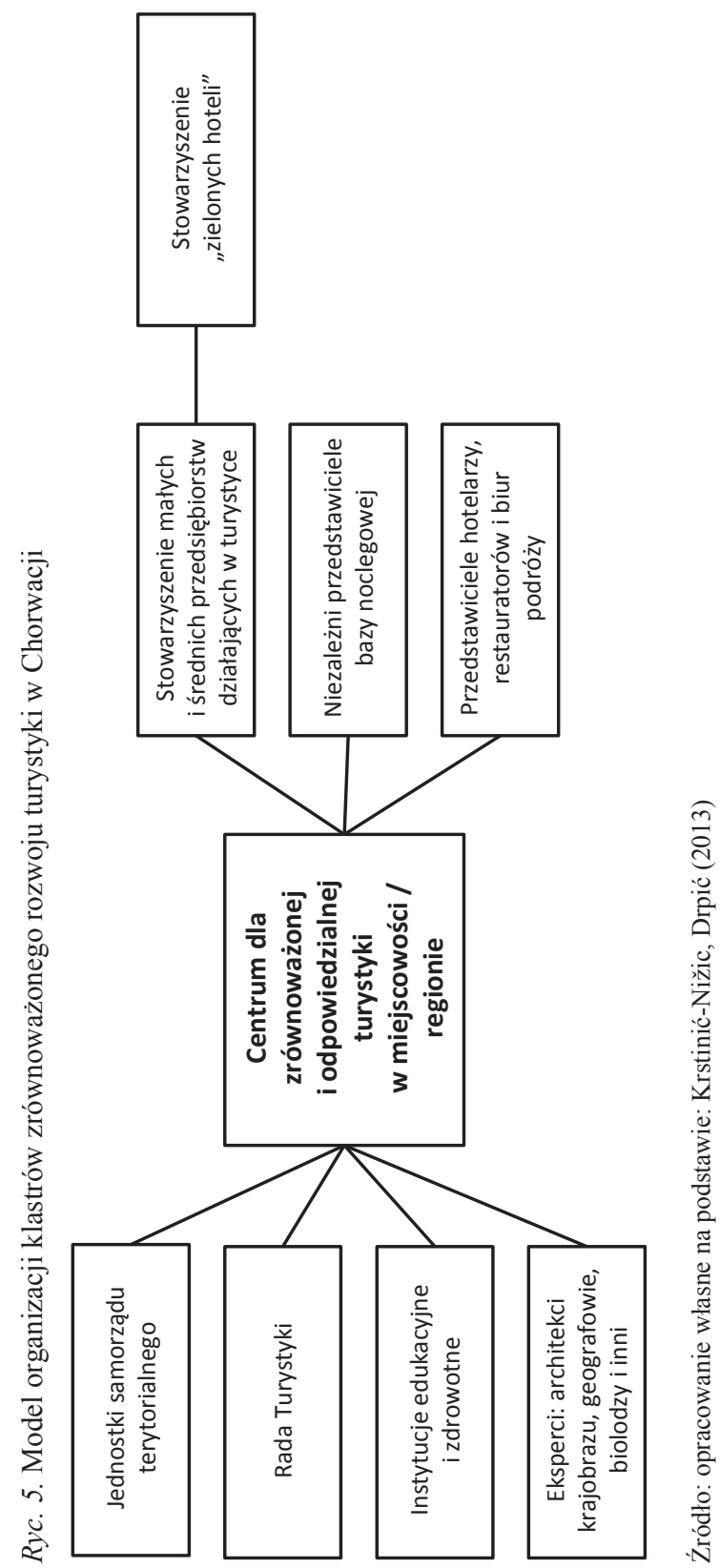


- ułatwienie dostępu do środków finansowych dla odpowiedzialnych i zrównoważonych projektów (Krstinić-Nižic, Drpić, 2013).

W celu osiągnięcia sukcesu zrównoważonego rozwoju turystyki potrzebne jest jasne i aktywne wsparcie na poziomie państwowym i na różnych poziomach lokalnych administracji. M. Krstinić-Nižic i D. Drpić (2013) proponują utworzenie centrum dla zrównoważonej i odpowiedzialnej turystyki regionów w Chorwacji (ryc. 5).

Dzięki takiemu rozwiązaniu możliwe jest, ,interdyscyplinarne podejście i synergia wszystkich, którzy mają wpływ na rozwój turystyki i mogą eliminować jej negatywne skutki” (Krstinić-Nižic, Drpić, 2013: 167). Przyjęcie takiego holistycznego i zintegrowanego podejścia do zrównoważonego rozwoju niesie za sobą wiele korzyści:

- dobrobyt gospodarczy:

- poprawa konkurencyjności oraz rentowność i dobra koniunktura przedsiębiorstw turystycznych,

- szanse na dobre zatrudnienie, sprawiedliwe płace i warunki pracy,

- równość i spójność społeczna:

- poprawa jakości życia lokalnej społeczności poprzez turystykę,

- zapewnienie turystom bezpiecznego i satysfakcjonującego doświadczenia wakacji,

- ochrona środowiska:

- minimalizacja zanieczyszczeń oraz degradacji środowiska globalnego,

- wykorzystywanie skromnych zasobów na potrzeby turystyki,

- utrzymywanie i wzmacnianie bogactwa kulturowego oraz bioróżnorodności (Dziatania..., 2014: 5).

\section{ZAKOŃCZENIE}

Zrównoważony rozwój turystyki uznawany jest za wytyczną co do sposobu zarządzania wszystkimi zasobami, by zarówno ekonomiczne, jak i społeczne potrzeby zostały zaspokojone, przy jednoczesnym zachowaniu kulturowej integralności i biologicznej różnorodności. W Chorwacji rozwinęła się turystyka masowa, utożsamiana z modelem $3 \mathrm{~S}$ (ang. sea, sun, sand). Powoduje ona poważną degradację środowiska oraz znaczne konsekwencje społeczne. Jednakże zrównoważona turystyka może być alternatywą dla turystyki masowej.

Chorwacja - podobnie, jak wiele innych rządów krajowych i władz lokalnych w Europie - zwróciła uwagę na kwestię zrównoważonego rozwoju. Jego założenia zostały oficjalnie rozpoznane, jednakże kluczowe wyzwania nie są powszechnie realizowane w tym państwie. Dzięki wprowadzeniu zrównoważonego modelu turystyki można zmniejszyć negatywny wpływ turystyki masowej, uzyskując tym samym wzrost konkurencyjności danego regionu. W dłuższej perspektywie powoduje to pozytywne skutki społeczne, gdyż dzięki temu poprawi się jakość życia lokalnej społeczności. Odpowiedzialna turystyka dba również o zasoby naturalne i środowisko, dzięki czemu Chorwaci mogliby z powrotem spojrzeć przychylnie na rozwój turystyki i powrócić do fazy euforii czy apatii. 


\section{Literatura \\ References}

Andriotis, K. (2006). Hosts, Guests and Politics - Coastal Resorts Morphological Change. Annals of Tourism Research, 33(4), 1079-1098.

Butler, R.W. (1980). The Concept of Tourism Area Cycle of Evolution: Implications for Management of Resources. Canadian Geographer, 24(1), 5-12.

Butler, R.W. (1999). Sustainable Tourism: a state of the art review. Tourism Geographies, 1(1), 7-25.

Cohen, E. (1972). Toward a Sociology of International Tourism. Social Research, 39, 164-182.

Doxey, G.V. (1975). A causation theory of visitor - resident irritants: Methodology and research inferences, W: Proceedings of the Travel Research Association 6th annual Conference. San Diego California: Travel Research Association, 98-195.

Działania na rzecz bardziej zrównoważonej turystyki europejskiej. Raport Grupy ds. Zrównoważonego Rozwoju Turystyki (TSG) (2014, 12 grudnia). Pozyskano z http://www.zarabiajnaturystyce.pl

Kowalczyk, M. (2011). Wskaźniki zrównoważonego rozwoju turystyki. Człowiek i Środowisko, 35(3-4), 35-50.

Krstinić-Nižic, M., Drpić, D. (2013). Model for Sustainable Tourism Development in Croatia. W: Tourism in Southern and Eastern Europe. Conference Proceedings from 2nd International Scientific Conference Tourism in South East Europe 2013. Crisis - a Challenge of Sustainable Tourism Development, 2, 159-173.

Krstinić-Nižic, M., Ivanović, S., Drpić, D. (2009). Spatial planning as the function of sustainability of theisland Krk. Ekonomska istraživanja, 22(3), 98-110.

Mathieson, A., Wall, G. (1982). Tourism Economic, Physical and Social Impacts. London: Longman.

Munasinghe, M. (2003). Analysing the Nexus of Sustainable Development and Climate Change: an Overview. Organisation for Economic Cooperation and Development. Pozyskano z http://www. oecd.org/dataoecd/32/54/2510070.pdf

Murphy, P.E. (1985). Tourism, a Community Approach. Nowy Jork: Methuen.

Neto, F. (2003). A New Approach to Sustainable Tourism Development: Moving Beyond Environmental Protection. Natural Resources Forum, 27, 212-222.

Petrić, L. (2012). Croatian Tourism Development Model - Anatomy of an Un/sustainability. W: C. Ghenai (red.). Sustainable Development. Rijeka: InTech, 119-147.

Popiel, M., Ziółkowska-Weiss, K. (2013). Croatian Tourism Products as a Tourism Generator and Economic and Social Determinant of this Country. W: J. Wyrzykowski, J. Marak (red.). Tourism Role in the Regional Economy. Regional Tourism Products - Theory and Practice. Wrocław: Wyższa Szkoła Handlowa, 543-554.

Rettinger, R. (2010). Turystyka jako czynnik aktywizacji gospodarki Chorwacji. PrzedsiębiorczośćEdukacja, 6, 450-461.

Ruoss, E., Alfarè, L. (red.) (2013). Sustainable Tourism as Driving Force for Cultural Heritage Sites Development Planning, Managing and Monitoring Cultural Heritage Sites in South East Europe. CHERPLAN project report. Pozyskano $\mathrm{z}$ http://www.southeast-europe.net/document.cmt?id=808

Swarbrooke, J. (1999). Sustainable tourism management. Wallingford, UK: CABI.

Tourism in Figures 2013 (2014). Croatia Ministry of Tourism. Pozyskano z http://business.croatia.hr/ Documents/3257/Tourism-in-Figures-2013.pdf

Marcin Popiel, mgr, Uniwersytet Jagielloński, Wydział Biologii i Nauk o Ziemi, Instytut Geografii i Gospodarki Przestrzennej, Zakład Gospodarki Turystycznej i Uzdrowiskowej. Geograf, pilot wycieczek, z zamiłowania zapalony turysta. Absolwent geografii Uniwersytetu Pedagogicznego w Krakowie. Od 2012 roku doktorant Uniwersytetu Jagiellońskiego na Wydziale Biologii i Nauk o Ziemi. Interesuje się badaniami nad atrakcjami turystycznymi oraz regionalizacją turystyczną. Specjalizuje się w zakresie turystyki osób niepełnosprawnych, innowacyjności i zarządzania w turystyce i hotelarstwie. 
Marcin Popiel, M.A., Jagiellonian University, Faculty of Biology and Earth Sciences, Institute of Geography and Spatial Management, Department of Tourism and Health Resort Management. Geographer, tour leader, for whom travelling is a great passion. Graduated geography at the Pedagogical University in Krakow. Since 2012 a PhD student at the Jagiellonian University, Faculty of Biology and Earth Sciences. Is interested in the study of regionalization and tourism attractions. Specializes in the field of accessible tourism, innovation and management in tourism and hospitality.

\section{Adres/address:}

Uniwersytet Jagielloński

Wydział Biologii i Nauk o Ziemi

Instytut Geografii i Gospodarki Przestrzennej

Zakład Gospodarki Turystycznej i Uzdrowiskowej

ul. Gronostajowa 7, 30-387 Kraków, Polska

e-mail: marcin.popiel@uj.edu.pl 